This document is published in (in Press):

European Constitutional Law Review, 2013, Vol. 9, pp. 189-204.

DOI: http://dx.doi.org/10.1017/S1574019612001113

(C) 2013 T.M.C. ASSER PRESS and Contributors 


\title{
The Spanish Legal Framework for Curbing the Public Debt and the Deficit
}

\author{
Violeta Ruiz Almendral* \\ Constitutional reform in Spain - Budgetary stability - Debt and deficit limits - Fis- \\ cal Compact - Six Pack - Two Pack - Fiscal federalism - 'State of autonomies' - \\ Financing of the autonomous communities - Adoption of an 'internal stability pact'
}

\section{INTRODUCTION}

On September 27, 2011, Article 135 of the Spanish Constitution was amended for the purpose of introducing deficit and debt rules. The reform, announced just a month earlier by then Prime Minister José Luis Rodríguez Zapatero, was adopted following a special procedure established in Article 167 of the Spanish Constitution, ${ }^{1}$ and was a speedy reaction to the unsustainably high cost of Spanish bond yields, which had climbed to a 7\% interest rate during August 2011 . $^{2}$ This constitutional reform was primarily intended to 'appease' financial markets and instill credibility in the Spanish economic system.

The new Article 135 refers to a future 'organic law's to fully implement the new measures. On 27 April 2012, Organic Law 2/2012, (Law on Budgetary Stability and Financial Sustainability) was approved to this end.

* Law Counsel (Letrada) at the Spanish Constitutional Court. Associate Professor (Profesora Titular) of Tax and Finance Law at the Universidad Carlos III de Madrid. This article was adapted from an article which appears in the Tijdschrift voor Constitutioneel Recht [Dutch Constitutional Law Review] (2013) p. 68. Professors Alain Cuenca and François Vaillancourt thoroughly read this manuscript and made useful suggestions that have considerably improved the original version. An anonymous reviewer also contributed to improve it. I would also like to thank Professor Jan-Herman Reestman for his patience in revising the paper, and Julie Nauman, who edited the final version.

${ }^{1}$ Section 167 states that bills on constitutional amendments must be approved by a majority of three-fifths of members of each house.

${ }^{2}$ See for example 'Spain's Economy. Split Personality', The Economist (7 July 2011), <www. economist.com/node/18929032?zid=295\&ah=0bca374e65f2354d553956ea65f756e0 >, visited 7 July 2011.

${ }^{3}$ Organic laws are laws approved by an absolute majority of parliament (Art. 81 Spanish Constitution) and are thus harder to amend (that is, 176 deputies out of a total of 350 must vote in 
The constitutional reform builds on an existing 'internal stability pact' legal framework, a set of laws approved in 2001 and reformed in $2006 .{ }^{4}$ This set of laws had the primary objective of coordinating the deficit in what in practice is a highly decentralized country, since the Spanish regions, known as 'autonomous communities', currently manage $35 \%$ of public spending, while local entities are in charge of $13 \%$. For this reason alone, an internal system to ensure that deficit and debt limits were controlled and coordinated was considered of paramount importance. The 2001 laws had been contested on the grounds that they limited the political autonomy of the Spanish regions. It was partly to address these complaints that the laws were amended in 2006.

As I write these lines, Spain's banks have already been 'bailed out', ${ }^{5}$ and a fullfledged bail out is not entirely out of the question for the Spanish economy. ${ }^{6}$ Furthermore, measures undertaken to curb the deficit may also be exacerbating the economic downturn, as tax revenues plummet and bank deposits leave Spanish banks, all making it increasingly harder to meet the debt and deficit targets. ${ }^{7}$ During 2012, the Spanish government approved a group of austerity measures to lower the debt and deficit. ${ }^{8}$ In this context, and with economic indicators and debt and deficit projections changing almost weekly, ${ }^{9}$ it is probably too early to fully assess the recent constitutional reform enshrining the debt and deficit limitations and the legal framework following it.

favour). Also, only the national parliament, (i.e., not the autonomous communities' parliaments) may pass such laws, which means that such laws are always the purview of the central state.

${ }^{4}$ The first Budgetary Stability Law was the 'Ley 18/2001, de 12 de diciembre, General de Estabilidad Presupuestaria', modified in 2006 by the 'Ley 15/2006, de 26 de mayo'.

${ }^{5}$ On 25 June 2012, the Spanish government formally requested 'external financial assistance' from the EU in the context of the ongoing restructuring and recapitalization of the Spanish banking sector. This was granted and approved on July 20, 2012. The 'Memorandum of Understanding on Financial-Sector Policy Conditionality' (MoU, hereinafter) signed earlier on July 10, details some of the measures to be approved by Spain in order to receive the financial assistance.

${ }^{6}$ The Financial Times editorial of August 28, 2012 (titled 'For the Good of Spain, Not the Party',) urged the Spanish government to request the bail out immediately. The Economist of Sept. 14, 2012, points in the same direction ('More Pain in Spain').

${ }^{7}$ In the press articles abound making this point; just to name two examples, see for instance: J. Surowiecki, 'Smash the Ceiling', The New Yorker, August 1, 2011, p. 23; Specifically for Spain, see W. Münchau, 'Spain Has Accepted Mission Impossible', Financial Times, 15 April 2012.

${ }^{8}$ Among the strictest, the measures approved on 13 July 2012 included controversial measures such as a significant increase in tax pressure (the personal income tax and the value added tax) and the reduction of the public servant's pay by about $7.5 \%$. See a summary of these measures at: $<w w w$. thespanisheconomy.com/SiteCollectionDocuments/en-gb/Public\%20Finances\%20and\%20Public\%20Debt/Public\%20Finances/120713\%20Additional\%20Fiscal\%20Measures.pdf>, visited 13 May 2013).

${ }^{9}$ Official economic indicators are now regularly updated and made available in English at $<$ www.thespanisheconomy.com>. 
One fundamental question is whether the existing legal framework failed, and if so, whether the new one can be expected to be more successful. The debt and deficit exploded in Spain as a consequence of the 2007 crisis, leading to the first 'excessive deficit procedure' against Spain in 2009. ${ }^{10}$ Experts agree that it was not the lack of a credible legal framework that caused or failed to correct the increase of the debt and deficit, but rather the economic crisis, which in Spain followed on the heels of the financial crisis. The first direct consequence of the financial crisis was the halting of the construction economy, a sector that in 2007 represented up to $13 \%$ of Spain's gross domestic product (GDP). ${ }^{11}$ This resulted in unemployment rates reaching $27 \%$ in 2013 , and caused, among other things, the plummeting of tax revenues in comparison to the 'boom years' of 2005-2007.

Quite obviously, the legal framework or 'internal stability pact' in place before the crisis did not prevent the breach of the deficit threshold in 2009, when the deficit amounted to $11.2 \%$ of the GDP. But it is unlikely that any legal framework would have been able to maintain a low deficit during a recession that proved much deeper than forecasted.

The purpose of this paper is to briefly explain the current Spanish legal framework to curb the debt and deficit introduced after the constitutional reform of September 2011, before the 'Six Pack'12 and the 'Fiscal Compact' (Treaty on Stability, Coordination and Governance or TSCG) ${ }^{13}$ were approved, and in so doing, to address two questions: to what extent has the reform changed the previous

\footnotetext{
${ }^{10}$ The first Commission report was published on 18 Feb. 2009. See the full procedure at http:// ec.europa.eu/economy_finance/economic_governance/sgp/deficit/countries/spain_en.htm>.

${ }^{11}$ Low interest rates following the euro and the expansion of savings banks ('Cajas de Ahorros'), smaller regional banks that were not sufficiently supervised, substantially contributed to a construction boom that turned into a 'bubble', which in Spain was abruptly pierced when borrowing became more difficult after the fall of Lehman Brothers, in 2008. There is a significant amount of literature on the excessive weight of construction and real estate; see the IMF Country Report No. 11/216, 'Spain: Selected Issues', <www.imf.org/external/pubs/ft/scr/2011/cr11216.pdf>, visited 13 May 2013, p. 6-10. For a summary of the unfolding of the Spanish crisis, see J. Juan et al., Nada es Gratis [Nothing is free], Fundación de Estudios de Economía Aplicada (FEDEA) (Ediciones Destino, 2011).

${ }^{12}$ The 'Six Pack' is the set of five regulations and one directive that modify the legal framework of the Stability and Growth Pack. See the short guide published by the Commission, which partly helps to navigate through what has become a labyrinth of legal rules: 'Six-pack? Two-pack? Fiscal Compact? A Short Guide to the New EU Fiscal Governance', <http://ec.europa.eu/economy_fi nance/articles/governance/2012-03-14_six_pack_en.htm>, visited 25 May 2013.

${ }^{13}$ On the Six Pack, the Two Pack and the Fiscal Compact, see K. Tuori, 'The European Financial Crisis -Constitutional Aspects and Implications', EUI Working Papers, Law 2012/28, p. 1, at p. 17. On the financial assistance mechanisms: A. de Gregorio Merino, 'Legal Developments in the Economic and Monetary Union during the Debt Crisis: The Mechanisms of Financial Assistance', Common Market Law Review (2012), p. 1613, at p. 1615.
} 
Spanish legal environment of debt and deficit limitation and what consequences will it have on the Spanish 'quasi-federal' model of autonomous communities.

\section{THE NEW LEGAL FRAMEWORK FOR CURBING THE PUBLIC DEBT AND THE DEFICIT}

The (new) Article 135 of the Constitution was approved well before the signing and ratification of the Fiscal Compact, whose Article 3(2) establishes that the contracting States shall approve 'provisions of binding force and permanent character, preferably constitutional, or otherwise guaranteed to be fully respected and adhered to throughout the national budgetary processes.' The Organic Law 2/2012, approved after the Fiscal Compact, closely follows its provisions (in particular Article 3(1), but it also builds on the previous Spanish legal framework to curb excessive debt and deficit.

In 2001, the 'internal stability pact' set strict deficit limitations for budgetary policy. In practice, the 2001 laws radically changed how the central government's budget was designed and applied, and as a result, the question of indebtment slowly began to creep into the financial agreements with the autonomous communities. But the question of curbing the deficit was not the main purpose of these financial agreements, which determine how communities are financed. ${ }^{14}$ It can in fact be argued that the 2001 internal stability pact did not provide sufficient incentives to strictly enforce the rules, which to some extent had no teeth, so that no real sanctions were imposed upon autonomous communities that failed to meet the deficit targets. ${ }^{15}$ Also, the rules only addressed the deficit, not the debt, so that communities were also able to increase their debt burden with relative freedom. Despite the obvious shortcomings of the existing legal regime, in the period $1997-$ 2007 deficit and indebtment were low and there was not much debate, in political or academic circles, on the subject. This was probably also due to the relatively good shape of Spain's finances in that period. In fact, the only ongoing debate concerned the question of whether the central government had the authority to impose debt and deficit limits on autonomous communities and local entities (see infra). It is not an overstatement to say that until 2010, there were barely even academic seminars on the subject of the internal stability pact and discussions on the financing system of autonomous communities typically ignored the debt

\footnotetext{
${ }^{14}$ The financing of autonomous communities is established in a central government law, currently Law 22/2009, Dec. $18^{\text {th }}$. The law follows the agreement between the centre and the communities, but it could eventually be approved without such agreement, as it is not mandatory from a constitutional perspective.

${ }^{15}$ In fact, some communities lowered their tax pressure as they were building larger deficits; see V. Ruiz Almendral, 'Sharing Taxes and Sharing the Deficit in Spanish Fiscal Federalism', 10(1) eJournal of Tax Research, (Australia) (at ssrn.com), p. 88, at p. 95-97.
} 
and deficit figures. In this context, the hasty approval of Article 135 of the Spanish Constitution was not subject to much previous debate either. ${ }^{16}$

The laws regulating the 'internal pact' were highly contested from the perspective of the financial autonomy of autonomous communities, and were challenged before the Constitutional Court on the grounds that they reduced the equal distribution of public funds and curbed the financial autonomy of the autonomous communities. The Court addressed these issues in its Opinion of 20 July (STC 134/2011), upholding the constitutionality of the laws. The constitutional reform took place only two months after that opinion. ${ }^{17}$

Article 135 reads as follows: ${ }^{18}$

1. All public administrations will conform to the principle of budgetary stability.

2. The State and the Self-governing Communities may not incur a structural deficit that exceeds the limits established by the European Union for their member states. An Organic Act shall determine the maximum structural deficit the state and the Self-governing Communities may have, in relation to its gross domestic product. Local authorities must submit a balanced budget.

3. The State and the Self-governing Communities must be authorized by Act in order to issue public debt bonds or to contract loans.

Loans to meet payment on the interest and capital of the State's Public Debt shall always be deemed to be included in budget expenditure and their payment shall have absolute priority. These appropriations may not be subject to amendment or modification as long as they conform to the terms of issue.

The volume of public debt of all the public administrations in relation to the State' gross domestic product may not exceed the benchmark laid down by the Treaty on the Functioning of the European Union.

\footnotetext{
${ }^{16}$ To be sure, a number of legal papers have been published after the Constitutional reform as a simple 'google scholar' search will show. However, before the constitutional reform, and despite the fact that several constitutional complaints had been filed, the issue did not spark much interest in the press or academia, (among the exceptions, see the author, in works quoted above and works quoted therein; in particular, see J.M. González-Páramo: 'El Estado y las Haciendas territoriales frente a los retos de la estabilidad presupuestaria' [The State and the Autonomous Communities Face the Challenge of Budgetary Stability], 66 Revista de Estudios Regionales (2003), p. 19, at p. 27; by the same author: Costes y beneficios de la disciplina fiscal: la Ley de estabilidad presupuestaria en perspectiva [Costs and Benefits of Budgetary Stability in Spain] (Madrid, Instituto de Estudios Fiscales 2001); R. Fernández Llera and C. Monasterio Escudero: '¿Entre dos o entre todos? Examen y propuestas para la coordinación presupuestaria en España' [Proposals for Budgetary Coordination in Spain], 195(4) Hacienda Pública Española (2010) p. 139 at p. 142.

${ }^{17}$ After the enactment of new Art. 135, the Constitutional Court has issued ten opinions, all ruling on the 2001 laws, but applying the new provision to the reasoning (Opinion 157/2011, 18 Oct. and Opinions 187, 188 and 189, 23 Nov., 195, 196, 197, 198 and 199, 13 Dec., and 203/2011, 14 Dec.).

${ }^{18}$ Official translation (see <www.congreso.es/consti/constitucion/indice/index.htm>, for a choice of the Spanish Constitution in different languages).
} 
4. The limits of the structural deficit and public debt volume may be exceeded only in case of natural disasters, economic recession or extraordinary emergency situations that are beyond the control of the State and significantly impair either the financial situation or the economic or social sustainability of the State, as determined by an absolute majority of the members of the Congress of Deputies.

5. An Organic Act shall develop the principles referred to in this article, as well as participation in the respective procedures of the organs of institutional coordination between government fiscal policy and financial support. In any case, the Organic Act shall address:

a) The distribution of the limits of deficit and debt among the different public administrations, the exceptional circumstances to overcome them and the manner and time in which to correct the deviations of each other.

b) The methodology and procedure for calculating the structural deficit.

c) The responsibility of each public administration in case of breach of budgetary stability objectives.

6. The Self-governing Communities, in accordance with their respective laws and within the limits referred to in this article, shall take the appropriate procedures for effective implementation of the principle of stability in their rules and budgetary decisions.

Section 1 and 2 enshrine the principle of stability for 'all public administrations' as regulated in secondary EU law, to which section 2 refers. The inclusion of the principle of stability is not a radical change or innovation of the Spanish legal system, at least to the extent that it was already mentioned in the previous laws (the internal stability pact) as well as in secondary EU law, which is part of Spanish law. But its inclusion in the Constitution facilitates the coordination between Spanish and European budgetary principles, and it also makes it easier to impose these limits to sub-national entities without the constant claim that it may limit their financial autonomy (enshrined in Article 156 of the Constitution). ${ }^{19}$

The reform also limits the public debt (section 3), not just the deficit. This is new as the internal stability pact only dealt with deficit limits.

The reform includes several elements of flexibility. A first element is that the specific deficit limitations are to be established in an organic law, which is easier to change than the Constitution (section 2). An organic law must also develop the other principles contained in the Article as well as establish how the autonomous communities and the municipalities participate in the process of distributing the deficit and debt threshold among the different entities. A second element of flexibility is that the deficit and debt limits may be transgressed in cases of 'natural catastrophes, economic recession or situations of extraordinary emergency that are

\footnotetext{
${ }^{19}$ From a strict legal perspective, the constitutional reform was not necessary (as there already was an internal pact in place), but it was unquestionably a very strong political instrument for putting budgetary policy at the forefront of the political agenda.
} 
beyond the central Governments control.' Such circumstances must be assessed by an absolute majority of congress (176 out of 350 deputies).

Section 5 refers the fundamental aspects of coordinating budgetary stability to an organic law (currently, the above-mentioned Law 2/2012). The Constitution mandates this law to develop the principle of stability as well as to establish how the autonomous communities and the municipalities will participate in the process of distributing the deficit and debt threshold among the different entities. The law will then establish how the 'pie' of total deficit and debt is distributed among subnational entities, as well as the possible sanctions to be applied to those entities that do not comply with the limits.

Article 135.6 directs autonomous communities to adopt the pertinent legislation, or modify existing legislation if needed, in order to comply with the constitutional provisions.

All in all, Article 135 closely follows the German reform (Articles 109 and 115 of the Grundgesetz) ${ }^{20}$ However, contrary to the German counterpart, Article 135 refers to an organic law for main elements of the regime, such as the actual debt and deficit targets and their distribution between the centre, the autonomous communities and the municipalities. Organic Law 2/2012, which entered into force in April 2012, essentially mimics the European framework (in particular Regulation 1175/2011) (secondary) Union law, the Fiscal Compact and even the Treaty establishing the European Stability Mechanism, to the extent that it treats the autonomous communities as member states (they may thus be 'bailed-out' and their budgets are closely monitored by the central government, which in this capacity resembles the Commission) and the Spanish Constitutional Court as the Court of Justice of the EU. Thus, for example, a bail-out mechanism was implemented in 2012, the 'Regional Liquidity Fund' (Fondo de liquidez autonómica), but it was conditioned on the communities' compliance with the budgetary measures or other economic or budgetary measures undertaken by the Ministry of the Treasury. ${ }^{21}$ In this regard, this Law goes well beyond the previous existing legal framework on the control of debt and the deficit. Autonomous communities have publicly aired their disagreement with what they regard as a severe limitation of

\footnotetext{
${ }^{20}$ As pointed out, among many others, by E. Cordero González, 'La reforma de la constitución financiera alemana en particular, el nuevo límite al endeudamiento de la federación y los Länder' [The Reform of the Financial Constitution in Germany], 29 Teoria y Realidad Constitucional (2012) p. 289 at p. 325-326. See a recent comparison of the 'golden rule' in different EU constitutions at: F. Fabbrini, 'The Fiscal Compact, the "Golden Rule" and the Paradox of European Federalism', pending publication and available at SSRN (<http://ssrn.com/abstract=2096227>).

${ }^{21}$ The regime is laid out in a Royal Decree (Real Decreto-ley 21/2012, de 13 de julio). See a summary in English at: <www.thespanisheconomy.com/SiteCollectionDocuments/en-gb/Public\%20 Finances\%20and\%20Public\%20Debt/Public\%20Finances/120713\%20Regional\%20Liquid ity $\% 20$ Mechanism.pdf>.
} 
their fiscal autonomy. However, so far only the Islas Canarias Community has filed a formal complaint before the Constitutional Court. ${ }^{22}$ At the same time, some autonomous communities ${ }^{23}$ have also begun approving their own laws regulating the stability obligations.

The new legislation changed the previous legal framework in several ways. The main change is the substantial limitation on the leeway of the autonomous communities to incur indebtment and deficit. After decades of legal reforms increasing both the taxing powers and financial autonomy of the communities, this may be the beginning of the restructuring of the distribution of fiscal and financial authority between the centre and the communities on a much larger scale. The changes the organic law brings can be summarized as follows:

Increased powers of the central government. Organic Law 2/2012 draws its authority directly and solely from Article 135 of the Constitution, not from articles of the Constitution [Article 149(1), paras. 11, 13 and 14, and Article 157(3)] which had until then been employed to guarantee the central government's power to curb the deficit and the debt. ${ }^{24}$ Article 10(3) of the Law empowers the central government to establish any measure necessary to ensure the full coordination of the budgetary policies of the autonomous communities, the municipalities and the central government.

Definition of the public sector. Organic Law (Article 2) stresses the need to include public enterprises and agencies in the notion of public administration in order to avoid gimmickry fiscal practices. Strictly speaking this is not new, but only a clarification of the previous rules. This rule is important because some communities used to 'hide' a part of their debt in other entities (mainly public enterprises). ${ }^{25}$

${ }^{22}$ Complaint No. 557-2013 was filed before the Court last Jan. 2013 (Recurso de inconstitucionalidad n. 557-2013), as published in the Official Gazette, 'Boletín Oficial del Estado' of 9 March 2013.

${ }^{23}$ So far, Catalonia and Aragón have both passed budgetary stability laws (Cataluña: Ley 6/2012, de 17 de mayo, de estabilidad presupuestaria. Aragón: Ley 5/2012, de 7 de junio, de Estabilidad Presupuestaria de Aragón).

${ }^{24}$ Art. 149 lays out the authority of the central government in ample terms, providing a list of areas: '1. The State shall have exclusive competence over the following matters:

(...)

11. ${ }^{\text {a }}$ Monetary system: foreign currency, exchange and convertibility; bases for the regulations concerning credit, banking and insurance.

13. ${ }^{\text {a }}$ Basic rules and coordination of general economic planning.

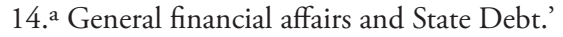

Art. 157(3) is (one of) the basis of the central government's coordination powers on the autonomous communities: 'the exercise of the financial powers set out in subsection 1 above, rules for settling the conflicts which may arise, and possible forms of financial cooperation between the self governing Communities and the State may be laid down by an organic act.'

${ }^{25}$ V. Ruiz Almendral, Estabilidad Presupuestaria y Gasto Público en España [Budgetary Stability and Public Spending in Spain] (Madrid, La Ley 2008), p. 269. 
(More) principles. Articles 3 to 10 enunciate a set of principles (stability, fiscal sustainability, multi-annual budget planning, transparency, efficiency, responsibility, and coordination) that should not only direct all public spending rules or regulations of the individual entities concerned, but also the relations among them. The stability principle, already present in the previous legal framework, is now defined as 'equilibrium' (Article 3(2)) or a zero structural deficit. ${ }^{26}$

Deficit target. The principle of a zero structural deficit target is enshrined in Article 11(2), but the deficit may be increased to a maximum of $-0.4 \%$ GDP if structural reforms with long term effects are undertaken. The wording mimics that of the Fiscal Compact (Article 3(3)(b)), but it is in fact stricter (except for the fact that it will not enter into force until 2020, as will be explained below).

Control of spending growth and expenditure ceiling. Article 12 rules that the growth rate of public spending of all entities (the centre and subnational) may not surpass the mid-term GDP growth. Article 30 requires all budgets to define an expenditure ceiling which must be met. ${ }^{27}$

Debt limits. Article 13 establishes debt limitations for the first time in the domestic rules on budgetary stability. But there is a caveat: together with the zero deficit target set by Article 11(2), these limitations will not be applicable until 2020, according to the Organic Law's first transitory provision. This of course means that until then the applicable limits will be those agreed with the EU institutions (currently within the framework of the Excessive Deficit Procedure) and included in the annual stability program (following the European semester) ${ }^{28}$

The enforcement of the reform and the internal distribution of the deficit and debt targets. Chapter IV of the Organic Law sets up a complicated system of sanctions directed at the municipalities and the autonomous aommunities. The system clearly follows the EU system: there is a 'prevention' phase where measures may be proposed to subnational entities and a 'correction' phase with the possibility of monetary sanctions. None of these measures have yet been implemented, although at least three communities (Valencia, Catalonia and Castilla-La Mancha), and especially the first two, are in breach of the criteria.

The role of the Constitutional Court. The new law enhances the role of the Constitutional Court, which has already played a fundamental role in shaping the Spanish State of Autonomies, in particular by interpreting the boundaries of the

\footnotetext{
${ }^{26}$ The notion of 'structural deficit' is not defined, but as can be inferred from the rest of the law, it refers to the end result of the economic cycle; that is, the zero deficit limits are not imposed in absolute terms.

${ }^{27}$ The growth rate limit had already been established in a royal decree (Real Decreto-ley $8 / 2011$, de 1 de julio), but it was then only binding for the central government and large local entities (such as Madrid, Valencia, Barcelona or Seville).

${ }^{28}$ The 2020 deadline has been controversial. It makes sense to the extent that the law sets a zero deficit rule, which is probably unsustainable in any scenario.
} 
respective level of authorities, which in most cases are shared by the centre and the communities. The new organic law (additional provision No. 3) states that any provision that contravenes Article 135 of the Constitution may be challenged before the Court. This seems unnecessary, since the Constitution already provides for this role of the Court (Article 161), unless of course its intention is to reinforce the traditional Court's role as umpire of the system.

\section{A re-Centralization of the Spanish 'state of autonomies'?}

Spain may not be a federal country by name, but the level of decentralization of public expenditures and, to a lesser extent, of taxation powers, equals that of many formal or traditional federations. Unlike the constitutions of other federal states, such as Germany, the Spanish Constitution of 1978 does not contain any reference to the system of the state. That is, it does not describe the state as either centralised, unitary, federal, or regional. After almost forty years of Franco's highly centralized government, consensus on this matter was hard to obtain. Nevertheless, the decentralization process in Spain has in financial (see Table 1$)^{29}$ and fiscal terms been a remarkable shift away from centralization. At least until the crisis, this decentralization had been well accepted by citizens. ${ }^{30}$

Table 1. Decentralization of public spending in Spain (percentage share of spending)

\begin{tabular}{lccc}
\hline Administration & 1982 & 1996 & 2009 \\
Central government $^{1}$ & 53 & 37.5 & 20.9 \\
Social security $^{1}$ & 32.5 & 29.2 & 29.9 \\
Autonomous communities $^{\text {Municipalities }}$ & 3.6 & 22.3 & 35.6 \\
\hline
\end{tabular}

Given this multi-level structure, Spain clearly needed to have a credible system to both coordinate and limit the debt and deficit of municipalities and autonomous

\footnotetext{
${ }^{29}$ See a good summary of that process, as well as the current situation of distribution of authority at: C. Colino and E. del Pino, 'Spanish Federalism in Crisis', in Paul Peterson and Daniel Nadler (eds.), The Global Debt Crisis. Haunting U.S. and European Federalism (Washington, Brookings Institution Press 2013 (forthcoming)).

${ }^{30}$ In a recent poll conducted by 'El Pais', $80 \%$ of respondents think the autonomous communities model should be 'reconsidered'. See also David Gardner. 'Spain: Autonomy under Fire', Financial Times (August 15, 2012), <www.ft.com/intl/cms/s/0/00d27e14-e63a-11e1-ac5f00144feab49a.html\#axzz245UeD4Zh>.

${ }^{31}$ Social security is a central government responsibility, but it has its own budget so it is usually disaggregated when presenting the debt and deficit projections.
} 
communities, an issue that had been almost completely off the political agenda until the crisis began ${ }^{32}$ despite the stability laws.

In 2002 the devolution process culminated in the transfer of health and education authority - by far the areas of greatest expense - to the autonomous communities. ${ }^{33}$ But, as has often been argued, the financial systems of autonomous communities approved in 2001 and 2009, established in central government law, failed to ensure both that communities would spend the necessary resources on these areas ${ }^{34}$ and that they would develop their own taxing policy to obtain further revenues. ${ }^{35}$ This is related to a fundamental structural problem, which is the lack of fiscal responsibility demonstrated by autonomous communities. The autonomies have generally been reluctant to use their taxing powers to raise revenue, and instead relied on government transfers or public debt, thereby avoiding the political cost of increasing tax pressure.

This is an old debate in Spain. In a book published in 1988, Antoni Castells had already argued that the level of fiscal responsibility should correspond to the level of devolution of authority. ${ }^{36}$ In 1995 , a report by a group of experts (known as the 'White Book' or 'Libro Blanco'), proposed different methods to increase the taxing powers of autonomous communities, in order to make them more account-

\footnotetext{
${ }^{32}$ In fact, the substantial 2009 reform of the autonomous communities' financing system focused more on their new taxing powers, or the extra revenues needed in order to finance health and education. It is also telling that the first draft of the Spanish Constitution included a provision curbing the autonomies' access to indebtment, which was discarded in the final version.

${ }^{33}$ They amount to about $80 \%$ of their public spending, see the estimation by C. Monasterio Escudero and J. Suárez Pandiello at Manual de Hacienda autonómica y local [Handbook of Local and Regional Finances] (Barcelona, Ariel 1998) p. 59. Although it does vary by autonomous communities, it is still a valid estimation.

${ }^{34} \mathrm{See}$ data and conclusions at A. Cuenca, 'Estabilidad Presupuestaria y endeudamiento autonómico en la crisis' [Budgetary Stability and Regional Indebtment], Cuadernos de Derecho Público, May 2012 (the author, Alain Cuenca, directed the high office for the coordination of budgetary policies between the centre and subnational entities until 2011 (named Dirección General de Coordinación Financiera con las Comunidades Autónomas y con las Entidades Locales), so the article contains substantial information on the period 2008-2011). See also by A. Cuenca, 'Estabilidad presupuestaria y Comunidades Autónomas', at Estabilidad presupuestaria y Sostenibilidad Financiera. (Madrid, Instituto de Estudios Fiscales 2013 (forthcoming)).

${ }^{35}$ See, among others, the work of A. de la Fuente (in particular: 'Qué reformas necesita el sistema de financiación regional?' [What Reforms Does the Regional Financing System Need?], at Fundación Sepi, May 2012, <www.fundacionsepi.es/ciea/Reforma\%20Financiacion\%20Autonomica\%20(Angel\%20de\%20la\%20Fuente).pdf>, visited14 May 2013); by the same author, see 'La evolución de la financiación de las comunidades autónomas de régimen común, 1999-2009' [The Evolution of Regional Financing] (Mimeo) (Instituto de Análisis Económico, CSIC), <http:// ideas.repec.org/p/aub/autbar/889.11.html>.

${ }^{36}$ A. Castells Oliveres, Hacienda Autonómica. Una perspectiva de federalismo fiscal. [Regional Finances. A Fiscal Federalism Perspective] (Barcelona, Ariel 1988).
} 
able for the revenues they obtained. ${ }^{37}$ The system was substantially transformed in 1997, when some taxes formerly managed by the Centre were turned into 'shared taxes', enabling communities to establish their own rates and deductions for some important taxes (such as the personal income tax). This shared taxation scheme was modified, and enlarged, in 2001 and 2009. But most communities in fact employed their newly enlarged taxing powers to establish tax deductions and thus lowered the tax pressure in their territories. ${ }^{38}$ This lack of fiscal responsibility has enhanced what in fiscal federalism literature is known as the 'vertical fiscal imbalance', or the situation that arises when one tier of government - usually the central state - has a greater power to obtain income than it actually needs for the exercise of its authority, while the other - subnational governments - is in the opposite situation. ${ }^{39}$

This is a problem for debt and deficit because when subnational governments receive financing almost exclusively in the form of transfers, an incentive to overspend those moneys is created. The idea is simple and similar to the 'moral hazard' ${ }^{40}$ problem: it is easier to spend revenue when, a) one does not withstand the political burden of having to raise it (i.e., establishing or raising taxes), and $b$ ) there is no need to explain the relationship between revenue raised and spent to voters/ taxpayers. The situation creates a lack of accountability that fosters the increase of debt and deficit.

${ }^{37} \mathrm{C}$. Monasterio Escudero et al., Informe sobre el actual sistema de financiación autonómica y sus problemas. [Report on the Current System of Regional Finances] (Madrid Instituto de Estudios Fiscales 1995).

${ }^{38}$ See examples and details of the financing systems at: V. Ruiz Almendral, 'The Asymmetric Distribution of Taxation Powers in the Spanish State of Autonomies: The Common System and the Foral Tax Regimes', 13(4) Regional and Federal Studies (2003) (Routledge, Frank Cass Journal; V. Ruiz Almendral and F. Vaillancourt: 'Choosing to Be Different (or Not): Personal Income Taxes at the Subnational Level in Canada and Spain', 29 Papel de Trabajo del Instituto de Estudios Fiscales (2006), and, most recently: V. Ruiz Almendral, 'Sharing Taxes and Sharing the Deficit in Spanish Fiscal Federalism', 10(1) eJournal of Tax Research (2012) (Australia), p. 88-125. See also the following three articles: J. Martínez-Vázquez, 'Revenue Assignments in the Practice of Fiscal Decentralization', in N. Bosch and J.M. y Durán (eds.), Fiscal Federalism and Political Decentralization. Lessons from Spain, Germany, and Canada (Cheltenham/Northampton, Edward Elgar 2008); J. López-Laborda et al., 'The Practice of Fiscal Federalism in Spain', in A. Shah (ed.), The Practice of Fiscal Federalism: Comparative Perspectives (Quebec, The Forum of Federations McGill-Queen's University Press 2010) p. 287-316; and A. Zabalza and J. López Laborda, 'The New Spanish System of Intergovernmental Transfers', 18 International Tax and Public Finance (2011) p. 750-786.

${ }^{39}$ Also referred to as the problem of 'fiscal mismatch', 'fiscal gap' or 'revenue gap', see: W.E. Oates, 'An Economist's Perspective on Fiscal Federalism', in W.E. Oates (ed.), The Political Economy of Fiscal Federalism (Toronto, Lexington Books 1977) p. 16.

${ }^{40} \mathrm{R}$. Boadway, 'Recent Developments in the Economics of Federalism', in H. Lazar (ed.), Canada: The State of The Federation 1999/2000. Toward a New Mission Statement for Canadian Fiscal Federalism (Kingston, Institute of Intergovernmental Relations 2000) p. 51. 
Furthermore, until 2011 the financing system of the autonomous communities did not sufficiently take into account the constraints of the EU Stability Pact. ${ }^{41}$ Moreover, as stated before, the sanctions in Spain's internal stability pact were not credible enough and communities were in practice able to run large deficits while reducing the tax pressure for their citizens. ${ }^{42}$

Together with the expenditure ceiling, the possibility of imposing sanctions, the reform has substantially altered the previous legal framework. It is too early, and the crisis is still too deep, to conclude what effects the new framework will have on the deficit and debt limits. But it is already clear that the budgetary processes and even the nature of the Spanish fiscal federalism system have been fundamentally transformed.

The new stability rules may facilitate a re-centralization of the powers of the autonomous communities. This is in line with the ongoing centralization that the Fiscal Compact and more generally the European Union's economic constitution are bringing about. ${ }^{43}$ These instruments not only entail centralization of powers, but also the transformation of the member states' economic constitutions. ${ }^{44}$ Also, the new internal stability may accelerate the process of re-centralization in which, as has already been suggested, Spain was already engaged.$^{45}$ One example concerns the process of distributing and sharing the deficit and debt 'pie' among different tiers of government. The system of intergovernmental relations between the centre and the communities which characterized the previous internal stability pact has been reshaped: the deficit and debt 'pie' is divided by the centre among communities, which have virtually lost all leeway to propose their own debt limits. Formal meetings in the 'Consejo de Política Fiscal y Financiera', an intergovernmental council where the Minister of the Treasury meets with the corresponding officials of the autonomous communities, ${ }^{46}$ is increasingly just a forum where the

\footnotetext{
${ }^{41}$ Political agreements between the central government and the communities, which took place under the auspices of the Consejo de Politica Fiscal y Financiera did address the issue of the communities' revenues, but omitted all reference to debt and deficit limitations.

${ }^{42}$ See Cuenca, supra n. 34, p. 163.

${ }^{43}$ See Fabbrini, supra n. 20, p. 24.

${ }^{44}$ See F. Snyder, 'EMU Revisited: Are We Making a Constitution? What Constitution Are We Making?', in P. Craig and G. de Búrca (eds.), The Evolution of EU Law (Oxford, Oxford University Press 1999) p. 418.

${ }^{45}$ See R. Máiz and A. Losada, 'The Erosion of Regional Powers in the Spanish "State of Autonomies"', in F. Requejo and K.J. Nagel (eds.), Federalism beyond Federations (Surrey, Ashgate 2011) p. 84 at p. $85-92$.

${ }^{46}$ The Consejo meets with closed doors and its minutes are not published, although its agreements eventually are (see <www.minhap.gob.es/es-ES/Areas\%20Tematicas/Financiacion\%20Auto nomica/Paginas/Consejo\%20de\%20Politica\%20Fiscal\%20y\%20Financiera.aspx>, visited 30 Aug. 2012.
} 
centre tells communities what their deficit/debt targets amount to, and what they must do to meet them. ${ }^{47}$

Furthermore, communities' control over their own budgets has substantially decreased, in particular because many of them have serious problems just meeting current payments, let alone future debt maturing payments. For that reason, several bail-out mechanisms have already been established. In 2012, two state-funded mechanisms to aid ailing communities were put in place: the 'payments to suppliers mechanism' ${ }^{48}$ and the 'regional liquidity mechanism'. This last fund, which was distributed among those communities that needed it in September 2012, is currently the subject of much debate. In 2012, the fund amounted to 18 billion euros. ${ }^{49}$ In 2013, this fund will reach an amount of 23 billion euros. ${ }^{50} \mathrm{On}$ top of this, or precisely because of this region bail-out system, the crisis has fostered a revival of the separatist debate. Cataluña, a community with a long tradition of nationalist supporters, has recently reopened the debate on the need to reform its financing system. ${ }^{51}$

\footnotetext{
${ }^{47}$ Communities have already had to undertake substantial measures to reduce spending. See details at: <www.minhap.gob.es/es-ES/Paginas/20120621_PEF_CCAA.aspx>, visited30 Aug. 2012.

${ }^{48}$ Regulated in two royal decrees: Royal Decree Law 4/2012, of 24 Feb., which sets out the obligations of information and procedures required for the establishment of a financing mechanism for the payment to suppliers of local entities and Royal Decree Law 7/2012, of 9 March, which provides for the creation of the fund for the financing of payments to suppliers.

${ }^{49}$ These figures and bail-out announcements have been extracted from the daily news of the three main Spanish newspapers ( $E l$ Pais, $A B C$ and $E l$ Mundo). To date, no official figures have been published. In 2012, the following communities benefited from the fund: Valencia, Murcia, Cataluña, Andalucía, Castilla-La Mancha, Canarias, Baleares and Principado de Asturias (all this, according to press releases. The official website of the Ministry of the Treasury contains no specific information on who is a beneficiary of thefFund).

${ }^{50}$ The figure is established in the 2013 National Budgetary Law.

${ }^{51}$ Catalonia currently has virtually the same level of authority as the rest of the autonomous communities, but it has traditionally shown a stronger interest in autonomy and thereby driven reform for the rest of communities. It was Catalonia's Statute in 1979 that set the agenda for a major reform in Spain, which was quickly transformed from a central-state model into a substantially decentralised country. It was also the need for the support of Convergencia I Unió (CiU) - the centre-right nationalist party - that made the different central governments (the Socialist Party in 1993 and the People's Party in 1996 and 2001) agree on a change of the financial system largely based on a model proposed by Catalonia. And once again, the 2001 and 2009 reforms of the financial system were largely driven by Catalonia's proposals. At the moment, Catalonia's public debt has ballooned to a $21 \%$ of GDP (from $7.4 \%$ in 2003). Following this data, the economist Xavier Sala i Martín, (among many others) has recently proposed full independence as the only way out: see 'The Catalan Bail-Out', <http://salaimartin.com/randomthoughts/item/405-the-catalan-bailout.html>, visited 31 Aug. 2012.
} 


\section{CONCLUDING REMARKS}

The new legal framework has also substantially altered the budgetary process. The first batch of stability laws in Spain (2001) had already brought about substantial changes in all aspects of the budget. In particular, it had transformed the budget procedure as defined in Article 134 of the Constitution. According to this article, the old process was purely domestic, starting with the government preparing a budget bill, which was then examined by the Parliament, executed by the government, controlled by the internal organs of the government (auditors at the Public Administration - Intervención General de la Administración del Estado) and, eventually, the Court of Auditors (dependent from parliament). Since the reforms, there is a phase 'zero', whereby the government presents the 'stability objective' or indicators of deficit and spending, which have been previously been examined by the Commission and must be approved by parliament. This objective is then the basis for the elaboration of the proposed budget (Article 15.7 of the Organic Law).

A blunt conclusion is that there is no longer $a$ budget controlled by parliament and the government alone. The current semi-bail out, or 'bail-out pending' situation, together with the excessive deficit procedure already in place, implies an enhanced supervision of the different phases of the budget via the European semester. $^{52}$

Furthermore, the whole process depends on projections of economic output, which are notorious for being volatile and thus unreliable. Already, after the implementation of the above-mentioned austerity measures, predictions are grimmer than the official figures serving to prepare the 2012 and 2013 budget projects. ${ }^{53}$ On July $10^{\text {th }}$ 2012, the Council of the European Union gave Spain an extra year to meet the deficit targets, which are now 6.3\% GDP for 2012, $4.5 \%$ of GDP for 2013 and $2.8 \%$ GDP for 2014 . The same document ${ }^{54}$ shows that the 2009 recommendations assumed growth rates that did not occur (a growth rate of $1 \%$ had been initially assumed for 2012 and 2013, compared with the $-1.9 \%$ and $-0.3 \%$

\footnotetext{
${ }^{52}$ As stated in the $\mathrm{MoU}$ : 'there is a close relationship between macroeconomic imbalances, public finances and financial sector soundness. Hence, progress made with respect to the implementation of the commitments under the Excessive Deficit Procedure, and with regard to structural reforms, with a view to correcting any macroeconomic imbalances as identified within the framework of the European Semester, will be regularly and closely monitored in parallel with the formal review process as envisioned in this MoU', Point 29 of the 'Memorandum of Understanding on Financial-Sector Policy Conditionality', July 2012.

${ }^{53}$ According to the latest (28 Aug. 2012) report by the National Institute of Statistics (INE), private consumption has plummeted following the reduction of salaries (see press release, <www. ine.es/prensa/cntr0212.pdf>, visited 29 Aug. 2012. See also the grim perspectives published by the IMF, at <www.imf.org/external/np/sec/pn/2012/pn1287.htm>, visited 29 Aug. 2012.

${ }^{54}$ See press release by the Council of 10 July 2012 (No. 12387/12), at <www.consilium.europa. eu/uedocs/cms_Data/docs/pressdata/en/ecofin/131676.pdf>, visited 31 Aug. 2012.
} 
rates currently estimated). According to the 2013-2016 Stability Program, submitted to the Commission on April 26, $2013,{ }^{55}$ real GDP will fall to $-1.3 \%$ (with an estimated growth of $0.5 \%$ for $2014,0.9 \%$ for 2015 and $1.3 \%$ for 2016). The deficit for 2012 was $-7.0 \%$ GDP, and the projection for $2013-6.3 \%$.

The weak link of the system, both the Spanish internal stability system and the EU rules (Fiscal Compact/Six Pack), is that it is largely based on measuring economic output and the attached variables. As the changing data demonstrate, ${ }^{56}$ the economic environment cannot be as predictable as the rule of law would like it to be. Designing a macro legal framework that may trigger such harsh consequences (such as requiring austerity measures, eventually imposing sanctions, etc.) but that is fundamentally based on contingent data, which increasingly also depends on volatile markets, is a dangerous situation which should be the subject of a deeper debate. Like military drones, ${ }^{57}$ the budget rules are in peril of becoming something akin to 'armed unmanned budgetary vehicles', well intended but whose consequences are hard to control or predict, going much beyond what Rawls may have anticipated in his famous 'veil of ignorance' analogy. ${ }^{58}$

\footnotetext{
${ }^{55}$ Available in English at <www.thespanisheconomy.com/SiteCollectionDocuments/en-gb/ Economic\%20Outlook/Stability\%20Programme\%202013-2016.pdf>, visited 13 May 2013.

${ }^{56}$ See the point made by M. Wolf, 'Mind the Gap: The Perils of Forecasting Output', Financial Times (8 Dec. 2011, on an article referring to the 'Office for Budgetary Responsibility' created in the UK.

${ }^{57}$ See A. Callam, 'Drone Wars: Armed Unmanned Aerial Vehicles', XVIII(3) International Affairs Review (2010), <www.iar-gwu.org/node/144\#comment-739>, visited 25 Nov. 2011).

${ }^{58} \mathrm{~J}$. Rawls, A Theory of Justice (Cambridge, MA, The Belknap Press of Harvard University Press 1971) (rev. edn. 1999) p. 118.
} 